\title{
Characterizing the Vertical Processes of Ozone in Colorado's Front RANGE USING THE GSFC OZONE DIAL
}

\author{
John T. Sullivan ${ }^{1,2 *}$, Thomas J. McGee ${ }^{3}$, Raymond M. Hoff ${ }^{1,2}$, Grant Sumnicht ${ }^{4}$, Laurence Twigg ${ }^{4}$ \\ ${ }^{I}$ Department of Physics, University of Maryland, Baltimore County, Baltimore, MD 21250, USA, \\ *Email: johnsullivan@umbc.edu \\ ${ }^{2}$ Joint Center for Earth Systems Technology, Baltimore, MD 21250, USA, \\ ${ }^{3}$ Atmospheric Chemistry and Dynamics Laboratory, NASA GSFC, Greenbelt, MD 20771, USA \\ ${ }^{4}$ Science Systems and Applications Inc., Lanham, MD 20706, USA
}

\begin{abstract}
Although characterizing the interactions of ozone throughout the entire troposphere are important for health and climate processes, there is a lack of routine measurements of vertical profiles within the United States. In order to monitor this lower ozone more effectively, the National Aeronautics and Space Administration (NASA) Goddard Space Flight Center TROPospheric OZone DIfferential Absorption Lidar (GSFC TROPOZ DIAL) has been developed and validated within the Tropospheric Ozone Lidar Network (TOLNet). Two scientifically interesting ozone episodes are presented that were observed during the 2014 Deriving Information on Surface Conditions from Column and Vertically Resolved Observations Relevant to Air Quality (DISCOVER AQ) campaign at Ft. Collins, Colorado.
\end{abstract}

The first case study, occurring between 22-23 July 2014, indicates enhanced concentrations of ozone at Ft. Collins during nighttime hours, which was due to the complex recirculation of ozone within the foothills of the Rocky Mountain region. Although quantifying the ozone increase aloft during recirculation episodes has been historically difficult, results indicate that an increase of 20 30 ppbv of ozone at the Ft. Collins site has been attributed to this recirculation. The second case, occurring between Aug 4-8th 2014, characterizes a dynamical exchange of ozone between the stratosphere and the troposphere. This case, along with seasonal model parameters from previous years, is used to estimate the stratospheric contribution to the Rocky Mountain region. Results suggest that a large amount of stratospheric air is residing in the troposphere in the summertime near Ft. Collins, CO. The results also indicate that warmer tropopauses are correlated with an increase in stratospheric air below the tropopause in the Rocky Mountain Region.

\section{INTRODUCTION}

Tropospheric ozone is an important trace gas to characterize because in abundance it can be harmful to humans and vegetation. Above the ground level, the enhancement of ozone has been historically difficult to measure directly due to its diurnal and season variability, relatively short lifetime and nonlinear formation. Tropospheric ozone concentrations within the planetary boundary layer in urban areas, such as the Denver, $\mathrm{CO}$ region, are typically dominated by photochemistry when local ozone precursor emissions, such as nitrogen oxides and certain volatile organic compounds, are concentrated near the surface in the presence of near ultraviolet sunlight. At higher altitudes, within the free troposphere, ozone is a key greenhouse gas and the sources can be classified as 1) dynamic Stratospheric-Tropospheric Exchange (STE), 2) advection from upwind sources and 3) regional redistribution from convection and/or lightning [1].

Although the interactions and processes of ozone throughout the entire troposphere are crucial for air quality and climate analyses, the uncertainty is rather high due to a lack of extended routine measurements of vertical profiles within the United States. To help aid in the current lack of tropospheric ozone profiles, the ground-based Tropospheric Ozone Lidar NETwork (TOLNet), which currently consists of five stations across the 
United States has been developed. The primary purpose of the instruments within TOLNet is to provide regular, high fidelity profile measurements of ozone within the troposphere, particularly the changing ozone dynamics and laminae inside the PBL.

As part of this network, the NASA Goddard Space Flight Center TROPospheric OZone DIfferential Absorption Lidar (GSFC TROPOZ DIAL) has been developed in a transportable trailer to take routine measurements of tropospheric ozone near the Baltimore Washington D.C. area and various campaign locations. Similar ground based instruments have been developed within TOLNet [2][3][4] but the GSFC TROPOZ DIAL is the first to measure ozone profiles near sea level directly in an urban environment within the mid-Atlantic U.S.

\section{THE DIAL METHOD}

For the DIAL technique, at least two different wavelengths are transmitted into the atmosphere. These wavelengths are chosen based on the spectral properties of ozone, the atmospheric constituent of interest. For this work [5], the TROPOZ transmitted wavelengths are generated by focusing the output of two frequencyquadrupled Neodymium-doped Yttrium Aluminum Garnet (Nd:YAG) laser beams (266 $\mathrm{nm}$ ), each into a pair of high pressure Raman cells, one filled with hydrogen and the other deuterium. Both cells have been optimized using helium as a buffer gas. The more absorbing wavelength, at $288.9 \mathrm{~nm}$, is called the "on" wavelength and the less absorbing wavelength, at $299.1 \mathrm{~nm}$, is the "off" wavelength. Because the inelastic Raman conversion is done prior to transmission into the atmosphere, and detection of atmospheric scattering is performed at the same transmitted wavelengths, the TROPOZ retrieval uses an elastic technique.

\section{OZONE RECIRCULATION CASE STUDY}

Over the last several decades, the population growth, complex terrain, and mesoscale meteorological conditions throughout Colorado's Front Range have been shown to favor severe pollution episodes [6]. An elevated ozone pollution episode was observed between 22-23 July 2014 during the DISCOVER AQ campaign, in which the Ft. Collins (Figure 1), NREL Golden, and BAO Tower sites exceeded the EPA National Ambient Air Quality Standard (NAAQS) 8-hour average of $75 \mathrm{ppbv}$. Several other ground sites also observed enhanced levels of ozone. However, the 8-hour exceedance that occurred at the Ft. Collins - West site was delayed by nearly two hours with respect to the other sites. For this reason, the elevated ozone was likely attributed to the additional recirculation and advection of ozone throughout the domain.

To understand the synoptic meteorological conditions for the domain during the test case, several NOAA national meteorological maps and surface ozone maps from the EPA AIRNOW network are presented. The on-board in situ ozone monitor and wind measurements from the NASA P3B, which performed several spiral down overpasses at multiple sites, are also presented. Lidar measurements of ozone, wind speed/direction, and aerosols are presented as well as several ozonesondes. A back trajectory of the polluted air mass is shown with the HYSPLIT trajectory model. These results are also compared to the meteorological and chemical output from a regional air quality model that was being initialized daily during the DISCOVER AQ campaign.

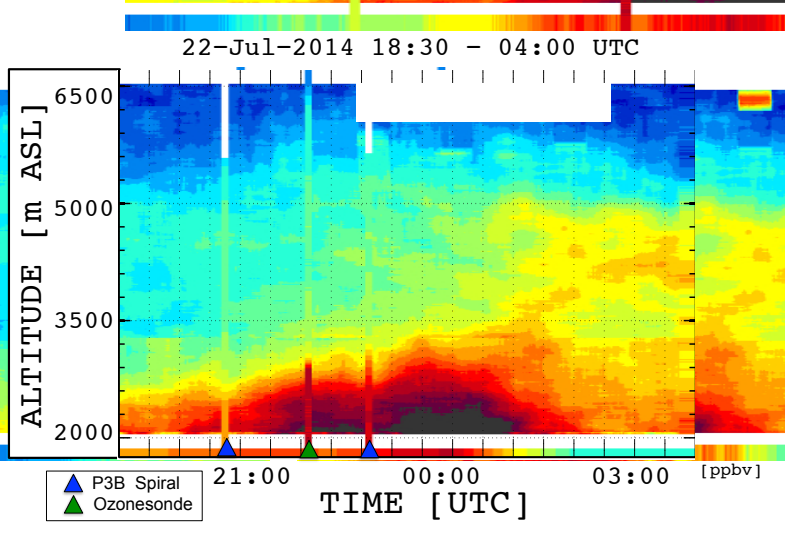

Figure 1: TROPOZ time series observations from Ft. Collins, CO during the DISCOVER AQ Campaign from 22-23 July 2014.

With the suite of models, surface monitors, profilers, and aircraft observations during the event, it is possible to show that the complex interactions of winds aloft and near surface winds were the coupled driving mechanism for the enhancement of ozone over the most of the campaign sites. More specifically, evening observations occurring after a very 
photochemically active ozone production day, indicate that 1) upslope winds advected elevated concentrations of ozone to high elevation mountain sites and during the upslope to downslope lower level wind reversal, ventilation was deterred which subsequently elevated ozone concentrations by $20-30 \mathrm{ppbv}$ at sites near the eastern ridge of the Rocky Mountains, and 2) a reversal in the aloft winds caused by a quickly moving cold front advected a southeasterly flow of polluted ozone-rich air from the Denver metropolitan area towards the Rocky Mountains, which helped to maintain elevated ozone at sites near the eastern ridge of the Rocky Mountains.

\section{STRATOSPHERIC TROPOSPHERIC EXHCAHNGE (STE) CASE STUDY}

Intrusions of stratospheric air into the troposphere and tropopause folds are typically prompted by upper level synoptic meteorology such as baroclinic waves and upper level frontogenesis in the jet stream region [7]. The frontogenetically induced ageostrophic cyclonic circulation forces stratospheric air down into the troposphere resulting in a folding of the dynamical tropopause [8]. For the mid-latitude Rocky Mountain region, stratosphere-troposphere exchanges (STE) and tropopause folds are typically induced by the formation of an upper level cut-off low pressure system and its associated trough in the presence of the polar front or subtropical jet stream [9].

Measurements made in instances directly involved in STE events or tropopause folds in the northern Hemisphere have been previously described in winter, spring, and fall. However, it is also important to characterize summertime STE events because the upper level meteorology favors the summertime occurrence of cut off low pressure systems and STE events. An interesting example of a summertime STE event occurred during the 2014 DISCOVER AQ mission. Because of the campaign, high-resolution lidar and ozonesonde observations were available to quantify the upper level ozone laminae and resolve the dynamics surrounding the event, which can be seen in Figure . One unique feature of this STE event is that it likely entrained regional wildfires during the subsidence and advection near the Rocky Mountain region. Along with detailed supporting observations, the intrusion and advection of a stratospheric air mass over the Rocky Mountain region from 04-08 August 2014 will be characterized.

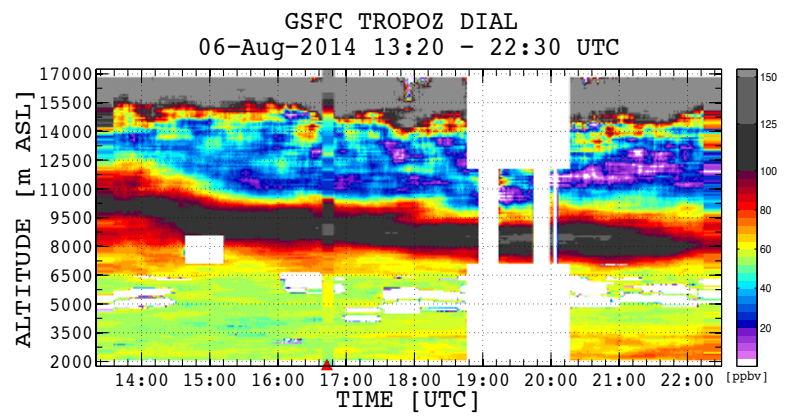

Figure 2: TROPOZ time series observations from Ft. Collins, CO during the DISCOVER AQ Campaign on 06 August 2014.

To emphasize the many similarities of the upper level dynamics that commonly induces STE events in the Rocky Mountain region, regardless of season, meteorological maps from a case study in each of the remaining seasons of 2014 are presented. In each STE event, the transfer of the dry, cold, and ozone-rich stratospheric air mass was associated with the presence of an Aleutian Low pressure system and developing cut off low near the Pacific coast of southern California. The air masses were quickly advected over the Pacific Southwest United States by a persistent southwesterly upper level tropospheric jet stream and eventually transported over the Rocky Mountain region.

During the summertime STE event, the Real-time Air Quality Modeling System (RAQMS) ozone output produced a very similar ozone filament in altitude and concentration to the TROPOZ and ozonesonde observations. Because of this agreement, the latter portion of this presentation will use RAQMS model output to analyze the stratospheric contribution to Ft. Collins and the Rocky Mountain region. To do this, a methodology of defining a correlation between the RAQMS ozone to potential vorticity ratio in the summertime STE event at Ft. Collins is determined. From this relationship, results suggest that 1) the occurrence of stratospheric air in the upper free troposphere from 2012-2014 is largely controlled by the temperature of the tropopause, in which warmer temperatures correlate well with larger occurrences of STE events and vice versa, 2) about one third of stratospheric air in Summer 2014 has resided below the tropopause for less 
than 12 hours, while another third has lasted 24 48 hours, implying some STE events are rather shallow, but nearly the same amount penetrate deeper in the troposphere, and observations during the Summer 2014 DISCOVER AQ campaign indicate that 3) a semi-permanent stratospheric reservoir exists in the free troposphere that is likely affecting the chemical and radiative budget at Ft. Collins.

\section{CONCLUSIONS}

Tropospheric ozone is an important trace gas to characterize because it can be harmful to humans and vegetation. The enhancement of lower tropospheric, or boundary layer ozone, typically occurs when local ozone precursors, such as nitrogen oxides and volatile organic compounds, are concentrated near the surface in the presence of near ultraviolet sunlight. At higher altitudes, in the free troposphere, ozone is a key greenhouse gas. Intrusions and layers of ozone occurring in the free troposphere are typically advected from local and regional sources or dynamically introduced from the stratosphere. Although the interactions and processes of ozone throughout the entire troposphere are crucial for air quality and climate analyses, there is a lack of routine measurements of vertical profiles within the United States.

The GSFC TROPOZ DIAL is a new and unique tool for the air quality community because it can provide a continuous, high resolution and novel perspective of ozone pollution episodes during the daytime from near the surface to the tropopause. Depending on the atmospheric event or scientific question the TROPOZ is intended to investigate, averaging of the data may be minimized to detect natural variability and small ozone fluctuations or maximized to reach higher altitudes for climatology purposes. The TROPOZ has been utilized, along with a suite of other instruments and models, to help better characterize the vertical processes of ozone.

\section{ACKNOWLEDGEMENT}

This work was supported by UMBC/JCET (Task \#374, Project 8306), the Maryland Department of the Environment (MDE, Contract \#U00P4400079), NOAA-CREST CCNY Foundation (Sub-Contract 740 \#49173B-02) and the National Aeronautics and Space Administration. The authors wish to also gratefully acknowledge the support for this study provided by Jack Kaye (NASA HQ), the NASA Tropospheric Chemistry Program and the Tropospheric Ozone Lidar Network (TOLNet).

\section{REFERENCES}

[1] Anne M. Thompson et al, 2003: Southern Hemisphere Additional Ozonesondes (SHADOZ) 1998-2000 tropical ozone climatology 2. Tropospheric variability and the zonal wave-one. J. Geo. Research: Atmospheres, 108(D2), 8241.

[2] I. Stuart McDermid, Georg Beyerle, David A. Haner, and Thierry Leblanc, 2002: Redesign and improved performance of the tropospheric ozone lidar at the Jet Propulsion Laboratory Table Mountain Facility. Appl. Opt., 41(36), 7550-7555.

[3] R. J. Alvarez et al., 2011: Development and application of a compact, tunable, solid-state airborne ozone lidar system for boundary layer profiling. J. Atmos. Ocean. Tech., 28(10), 1258.

[4] Shi Kuang, Michael J. Newchurch, John Burris, and Xiong Liu, 2013: Ground- based lidar for atmospheric boundary layer ozone measurements. Appl. Opt., 52(15), 3557-3566.

[5] J. T. Sullivan, T. J. McGee, G. K. Sumnicht, L. W. Twigg, and R. M. Hoff, 2014: A mobile differential absorption lidar to measure sub-hourly fluctuation of tropospheric ozone profiles in the Baltimore - Washington, D.C. region. Atmos. Meas. Techniques, 7(10), 3529-3548.

[6] William D Neff. 1997: The Denver Brown Cloud studies from the perspective of model assessment needs and the role of meteorology. J. of Air \& Waste Mgmt. Assoc., 47(3), 269-285.

[7] Edwin F Danielsen, 1968: Stratospherictropospheric exchange based on radioactivity, ozone and potential vorticity. J. of the Atmospheric Sciences, 25(3), 502-518.

[8] M Beekman et al., 1997: Regional and global tropopause fold occurrence and related ozone flux across the tropopause. J. of At. Chem., 28, 29.

[9] AO Langford, CD Masters, MH Proffitt, E-Y Hsie, and AF Tuck, 1996: Ozone measurements in a tropopause fold associated with a cut-off low system. Geophy. Res. Letters, 23(18), 2501-2504. 